\title{
Vicente Ráo - mestre de Direito Civil*.
}

\author{
Ernesto Leme \\ Catedrático de Direito Comercial da Faculdade \\ de Direïto da Universidade de São Paulo.
}

Senhor professor Vicente Ráo.

Corria o mês de março de 1908. Nos gerais do antigo convento franciscano aglomerava-se uma multidão de estudantes. Os veteranos, já donos da Casa, olhavam com curiosidade os colegas do primeiro ano. Eram cento e sessenta os novos matriculados, alguns poucos alunos do segundo ano e com débito de novos exames com o professor Reynaldo Porchat. Era êste uma das figuras primaciais da Academia. Ainda jovem, no esplendor de seus quarenta anos, a todos impressionava pela dignidade de seu porte e de suas atitudes. Ao lado de Brasílio Machado, empunhava o facho da oratória acadêmica. Por isso mesmo, as suas aulas de Direito Romano, na sala n. ${ }^{\circ}$, exerciam uma atração irresistível para seus discípulos.

Entre os calouros que então se iniciavam nos estudos jurídicos, muitos viriam exercer papel relevante na vida pública. "Ce n'est pas la source qui fait connaître si le cours d'eau sera un grand fleuve ou bien un petit torrent", (Joaquim Nabuco, Pensées Détachées). Encontramos nessa turma futuros secretários de Estado, desembargadores, advogados insignes, ao lado de três mestres de direito, um poeta da prosa, Edvard Carmilo e um principe dos poetas, Guilherme de Almeida.

* Discurso proferido na homenagem prestada pelo Instituto dos Advogados de São Paulo, a 16 de junho de 1962. 
A amizade fraterna que a êste sempre vos uniu, senhor professor Vicente Ráo, revela-se até mesmo nas assinaturas apostas no livro de matrícula. Comparecestes juntos à Academia para essa formalidade, tendo Guilherme na inscrição o n. 21, vós o n. 22.

Vejo nessa ligação profunda das duas almas a explicação para o fato de terdes ido trabalhar, ainda estudante, ao lado de Estevam de Almeida, mestre de todos nós. Nesse escritório iria encontrar-vos, em 1910, Francisco Morato, ao transferir sua banca de advogado para esta Capital. Com êsses dois guias insuperáveis fizestes vosso noviciado na profissão. E conseguistes galgar, na advocacia e no professorado, prestígio igual ao dêsses eminentes jurisconsultos.

$\mathrm{Na}$ vida pública, porém, tivestes oportunidade, que jamais procurastes, de exercer papel de relêvo que o destino não reservou u êsses ilustres brasileiros. Ministro de Estado da Justiça e Negócios Interiores, de 1934 a 1936, Ministro de Estado das Relações Exteriores, de 1953 a 1954, vossa influência na política interna e externa do País veio pôr em destaque, de mâneira tão significativa, os vossos atributos de estadista.

Não me cabe apreciar neste instante essa face de vossa carreira. Dela vai ocupar-se o embaixador João Neves da Fontoura, parlamentar, diplomata, escritor, orador exímio, que foi no Parlamento, em 1930, a "grande voz da Aliança Liberal. Não resisto, contudo, à tentação dè aludir a dois episódios, de que fui testemunha, os quais assinalam, com especial relêvo, não só vosso merecimento de jurisfa, como o vosso inegável tacto diplomático.

O primeiro se passou em Caracas, em março de 1954, durante a x Conferência Interamericana, na qual presidistes a Delegação do Brasil. Forster Dulles havia apresentado a sua proposição no sentido de se adotarem na América providências tendentes à repressão do comunismo internacional, que então já constituía uma ameaça no continente. Em hábil discurso tentou o solerte chanceler da Guatemala torpedear a resolução, propondo que inicialmente um grupo 
de representantes fôsse incumbido de estabelecer o conceito de "comunismo internacional", desconhecido por todos...

Ante a indecisão geral, proferistes, senhor professor Vicente Ráo, vosso empolgante improviso, que tanta impressão causou em todo o hemisfério. Sôbre êle me falaram, cheios de admiração, embaixadores de outros países, meus colegas na oNU; teceu-lhe as mais honrosas referências o Secretário Geral da Organização, Dag Hammarskjoeld, meu sempre lembrado amigo, morto tràgicamente no Oriente, quando em missão de Paz.

O segundo ocorreu em Nova York, em junho do mesmo ano, quando eu exercia, honrado com a vossa confiança e a do Chefe de Estado, as funções de Delegado Permanente do Brasil nas Nações Unidas e Representante no Conselho de Segurança.

Estava em debate no Conselho a matéria concernente à situação da Guatemala, onde as fôrças em conflito punham em perigo a paz internacional. Qualquer deliberação daquele órgão sôbre as medidas efetivas a serem adotadas no caso seria inócua, ante a perspectiva de veto da União Soviética, aliada do govêrno de Arbenz.

$\mathrm{Eu}$ me encontrava nesse instante recolhido ao Presbyterian Hospital, onde me submetera a delicada intervenção cirúrgica, em virtude de descolamento da retina. Subtituíame na Chefia da Delegação o ministro Hugo Gouthier. Foi quando êsse dedicado companheiro, em comunicação telefônica com o Rio de Janeiro, recebeu instruções diretas do Ministro de Estado para submeter ao Conselho um projeto de resolução, pelo qual a matéria deveria ser apreciada prèviamente pela Organização dos Estados Americanos, voltando após às Nações Unidas com informação sôbre as providências adequadas no caso. Era uma questão processual, que não possibilitava o veto de qualquer membro permanente do Conselho, nos têrmos do art. 27, Ir, da Carta.

O delegado substituto levou o assunto ao meu conhecimento, no leito do hospital em que me encontrava. Concordei sem demora com a solução aventada. E, subscrita a 
proposição brasileira pelo representante da Colômbia, foi ela aprovada por dez votos, contra o voto do representante da União Soviética.

Nosso representante no Organismo Regional, embaixador Fernando Lobo, obteve prontamente fôsse constituída uma comissão, para examinar in loco as causas do conflito; mas, no dia seguinte, caía o govêrno comunista de Arbenz. No mês de julho, exercendo eu a presidência do Conselho de Segurança, recebi do govêrno da Guatemala solicitação para que fôsse retirada da agenda a queixa referente a êsse país, pois a paz já se encontrava plenamente restabelecida.

Os sucessos de 24 de agôsto de 1954, com o sacrifício da vida do presidente da República, vieram interromper vossa atividade de estadista e permitir retornásseis à vossa faina de jurista e ao exercício da cátedra, que tanto honrastes. O que sempre distinguiu vossa ação na vida pública foi o culto do direito. Desde quando, sem haverdes completado dezesseis anos de idade, iniciastes vossos estudos na Faculdade de Direito, o fenômeno jurídico passou a interessar-vos de perto, seduzido pela História Externa do Direito Romano, ou vos esforçando para penetrar na intimidade das escolas filosóficas.

São incontáveis os trabalhos que produzistes na especialidade, quer no campo do Direito Público, quer no do Direito Privado. Dezenas dêles constam de opúsculos que publicastes, no trato da advocacia, ou foram insertos em revistas de jurisprudência.

Desde os primeiros passos na vida do Instituto dos Advogados de São Paulo, colaborastes em seus trabalhos, debatendo em plenário os temas jurídicos sujeitos à discussão. O primeiro presidente do Instituto foi vosso mestre, Francisco Morato; representou a classe dos advogados, na sessão inaugural, vosso mestre, Estevam de Almeida. E o discípulo comungou com os mestres na projeção desta Casa, nos anos iniciais de sua existência.

Já em sessão plenária de 18 de outubro de 1918, vós vos pronunciáveis a respeito da capacidade civil da mulher 
casada, opinando que o Código Civil, introduzindo notáveis reformas no direito pátrio, ampliou tal capacidade, situandose em posição intermediária entre os extremos da incapacidade geral, da antiga legislação e a capacidade sem limites de legislações alienígenas. Essa matéria voltou a preocuparvos, na monografia publicada em 1922 pela Livraria Acadêmica, assim como na tese de livre escolha oferecida à Faculdade de Direito, em 1926, para o concurso de Direito Civil e na qual dissertastes sôbre os Direitos da mulher casada sôbre o produto de seu trabalho. A tese obrigatória foi sôbre a Posse dos direitos pessoais, tema já versado magistralmente pelo Conselheiro Ruy Barbosa e no qual puzestes o cunho de originalidade e a clareza, que distinguem todos os vossos trabalhos.

No concurso para a cátedra de Direito Civil, vaga mercê da jubilação do professor José Ulpiano Pinto de Souza, estavam inscritos seis candidatos. Três apenas se submeteram às provas regulamentares e nelas colhestes a palma da vitória, classificando-vos em primeiro lugar.

Tenho bem viva a lembrança dêsse prélio magnífico, em que, argïido pela Comissão Examinadora, composta dos professôres Octavio Mendes, Spencer Vampré, Josẻ Augusto Cesar e Manuel Pacheco Prates, sôbre as dissertações apresentadas, revelastes vossos invulgares dotes de polemista e perfeito conhecimento da matéria em foco. $\mathrm{E}$ a prova didática, que versou sôbre o tema - Da responsabilidade civil do Estado pelos atos do Poder Judiciário -, demonstrou, para os que não vos conheciam de perto, o expositor lúcido que sois, dotado de uma memória surpreendente e inteiramente seguro da doutrina esposada. Tivestes, da quase unanimidade da Congregação, a nota máxima e obtivestes a média geral de $\mathbf{9 , 7 5}$.

Estáveis então em plena maturidade. Ascendestes à cátedra no esplendor dos 35 anos e o vosso ingresso no professorado universitário abriu uma fase nova em vossa carreira de jurista. 
Convidado, em 1929, pelo dr. Levi Carneiro, presidente do Instituto da Ordem dos Advogados Brasileiros, para proferir uma conferência, no Curso de Altos Estudos Jurídicos, inaugurado por Clóvis Bevilaqua, vossa atração pelo Direito Comparado iria levar-vos a estudar $O$ Direito de Família na Legislação Soviética, trabalho êsse que vos inspirou os comentários que fizestes ao Código das leis do casamento, da família e da tutela, precedidos de uma exposição e crítica do sistema, compendiados no volume Direito da Familia dos Soviets.

Voltou-se então a vossa atividade para o campo do Direito Público. Escrevestes, para As novas tendências do Direito Constitucional, de Mirkine-Guetzévitch, vosso amigo de Paris, o Prefácic para a edição brasileira de sua obra. E realizastes na Faculdade de Direito, em 1933, o notável curso de extensão universitária sôbre as Novas formas de organização política. Cumpre ainda pôr em destaque vosso Esbôço de Constituição Federal, fruto dos debates travados no Instituto em tôrno da matéria. Tudo assim estava vos indicando para a cadeira de Teoria Geral do Estado, do Curso de Doutorado e na qual fôstes investido após a transferência da Faculdade de Direito para o Estado de São Paulo, pelo decreto n. 24.102, de 10 de abril de 1934 .

Ao deixardes, em 1954, as funções governamentais, em que tão assinalados serviços prestastes ao nosso País, pudestes retornar à vossa tenda de trabalho e prosseguir em vossa fecunda produção científica. Vossos pareceres foram sempre disputados, para aclarar as mais intrincadas contendas judiciárias. E pudestes então, gozando de relativa calma em vossa vida, dedicar-vos à obra máxima de vossa atividade de mestre do Direito Civil, publicando o $2 .^{\circ}$ volume de $O$ Direito e a vida dos Direitos, cujo $1 .^{\circ}$ volume, em dois tomos, é de 1952, assim como a recentíssima monografia sôbre Ato jurídico.

Nessas obras de tão alto merecimento selastes definitivamente vossa reputação de filósofo e de jurisconsulto. Não vos limitastes à exposição fria da matéria, como decorre do 
exame da legislação. Descestes à perquirição dos princípios que inspiraram essas normas, à fundamentação filosófica dêsses princípios, traçando-lhes a doutrina verdadeira.

Merece lido e meditado o capítulo introdutório de $O$ Direito $e$ a vida dos Direitos. São páginas de fino lavor literário e constituem a estratificação de uma cultura sedimentada em bases de uma conviccão profunda, firmada em quarenta anos de estudo e de reflexão.

No instante em que "para se estudar o direito, ou para aplicá-lo, já não se parte do estudo do homem, de sua personalidade, de sua natureza de sêr dotado de vida física e psíquica, isto é, material, mental, moral e espiritual," o vosso livro constitui um toque de rebate, para que se retornem aos princípios eternos, que constituem a essência da própria dignidade humana. Em sua Mensagem de Natal, de 1944, Pio xIr proclamava que, "longe de ser o objeto, ou como que simples elemento passivo da vida social, o homem é, pelo contrário, e deve ser e permanecer, o seu sujeito, o seu fundamento e o seu fim". Conceito êsse que o Santo Padre João xxiII, na Mater et Magistra, definindo os fundamentos da doutrina católica, assim reafirma: "O ponto principal dessa doutrina é que os homens, cada um em particular, constituem, necessàriamente, o fundamento, a causa e o fim de tôdas as instituições sociais"...

Recordastes o episódio referido por Tolstoi, de um oficial russo, que batia em um soldado desviado da fileira. "Não tem vergonha em tratar por êste modo um seu semelhante? Você nunca leu os Evangelhos?" inquiriu o escritor; ao que o militar, seu colega, retorquiu: " $E$ você nunca leu os regulamentos militares?" E concluís, citando Julien Benda, que "todos quantos quiserem regular o material, o temporal, pelo espiritual, sempre receberão esta resposta"...

Firmais a vossa doutrina em têrmos indisputáveis, sustentando que o direito não é apenas "um conjunto de regras técnicas destinadas a disciplinar certos fatos sociais, à medida em que se manifestam, sem visar um fim superior, 
um fim mais alto do que a solução imediata, empírica e material, de um conflito. Se, em harmonia com a natureza do homem, criatura dotada de razão e de consciência, o direito disciplina a vida social, após haver estabelecido esta disciplina, não abandona o sêr humano à sua própria sorte, antes, lança-o no caminho da perfeição, do desenvolvimento e do progresso, não só de sua vida física, mas também de sua vida psíquica, para constituir, por êste modo, sim, uma coletividade melhor formada por sêres melhores".

Cônscio das dificuldades existentes, agravadas sobremaneira nestes dez anos decorridos após a enunciação dêsses conceitos, a voz da experiência inspirou-vos estas frases lapidares: "As transformações, quando não se processam por meios revolucionários, processam-se por via de legislações desordenadas, tumultuárias, que só com o tempo se condensam e restabelecem a continuidade histórica do Direito. É nessa fase, mais do que em qualquer outra, que o jurista deve intervir e reafirmar os princípios básicos do Direito, cujo sacrifício importaria o da inteira ordem jurídica e o rompimento brutal com o passado".

Assim falou o jurista e o patriota. Assim julgam os homens de pensamento e de responsabilidade. Medite a mocidade sôbre essas palavras e as propague. Saibam os homens da lei fixar nos Códigos os princípios inelutáveis, a que a sociedade há de subordinar-se, se não quiser perecer.

A vossa última obra, Ato jurídico, deveria constituir uma parte da anterior. Pela extensão da matéria, resolvestes fôsse ela um trabalho autônomo. Modestamente a qualificastes de simples ensaio; mas, na verdade, é uma monografia que não encontra similar em nossa literatura jurídica.

Dividistes o livro em quatro títulos: (a) os fatos jurídicos e sua classificação, os atos jurídicos e suas espécies; (b) os requisitos dos atos jurídicos, pressupostos e elementos essenciais; (c) o conflito entre os elementos volitivos e a declaração; (d) os elementos acidentais dos atos jurídicos. 
Examinastes nesse volume tôdas as doutrinas, meditastes sôbre a opinião dos autores, perquiristes outras legislações. São 462 páginas, que se lêem com encantamento e proveito, pela lucidez da exposição, abundância de doutrina, indicação completa das fontes. Como em $O$ Direito e a vida dos Direitos, poderíeis repetir neste passo: "Nem pensei em afastar, de mim, a obsessão de ser claro, advertido, embora, de que a clareza tem o defeito de fazer parecer superficial. Não inferi dêsse aviso a conveniência de ser obscuro, para parecer mais profundo".

Ato juridico seria a vossa obra definitiva se, no albor de vossos primeiros setenta anos, não dispuzésseis ainda de uma resistência física insuspeitada e de um vigor intelectual que vos assegura uma posição de primeira plana, entre os jurisperitos e os pensadores brasileiros. De vós esperam os estudiosos os volumes complementares de vossa obra de direito civil, nos quais abordareis os Momentos e vicissitudes dos direitos, desde o seu nascimento até a sua extinção, assim como a Teoria geral dos direitos em espécie.

Senhor professor Vicente Ráo, o. Instituto dos Advogados de São Paulo, cuja presidência exercestes em dias pretéritos, festeja hoje em vós o término de uma gloriosa carreira de professor universitário. Mas, não nos equivoquemos: o vosso magistério continua. Através dos livros que escrevestes e daqueles que ides publicar, continuareis difundindo pelo País os frutos de uma grande cultura. Deixastes, em verdade, de ser o professor; mas, permaneceis o mestre de direito que sempre fostes. Esse o laurel que vos cahe, com inteira justiça; e não poderíeis ambicionar mais alta recompensa. 